\title{
醬油色素の比色定量法に就て
}

\author{
農學士染井冬史 \\ (昭和二年八月九日受理)
}

緒容

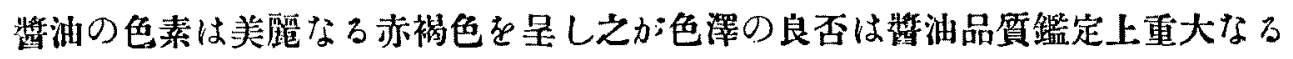
要素のーなb

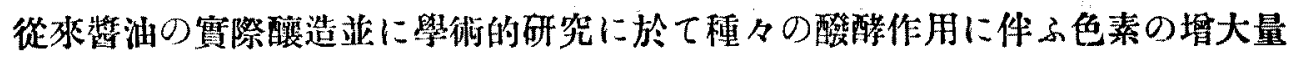
を测定せんとする際或は着色㧧の品質を撰擇し又は之を適當量に添加せんこする 際の如き場合賽驗者の等しく不便を感ずるは該色素の漫度を定量的に測定し得ざ ろ點ならとす

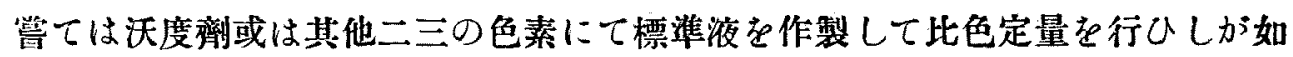

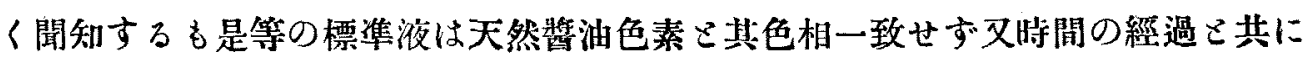

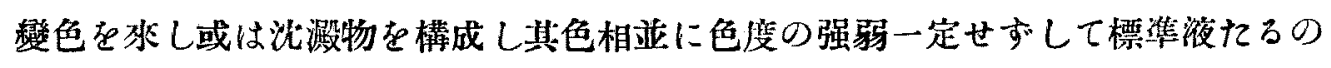
價值なし之れ著者が該色素の磪筫なる定量法の設定を企畫せる所以なりこす

獎油色素の化學的組織に關しては該色素の分離及純化共に至醮なるが故に既徍 之が研究に手を染むる者無かりしも最近農學博士黑野勘六氏及工學士勝目英氏

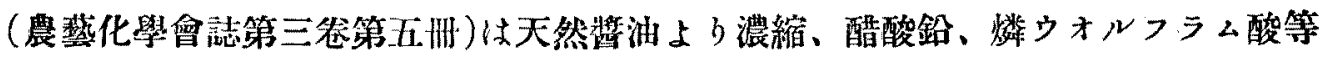
を以て反複色素を浓澱さしめ遂に灰分、蛋白留、炭水化物及游離アミノ酸を存在 せざる殆ご純粹なる色素の非結晶性粉末を得たり且つ之れが原素の組成を研究し 又分子量を测定し其他の化學反應等上り該色素は $\left(\mathrm{C}_{27} \mathrm{H}_{17} \mathrm{~N}_{3} \mathrm{O}_{13}\right)$ なる分子式を有

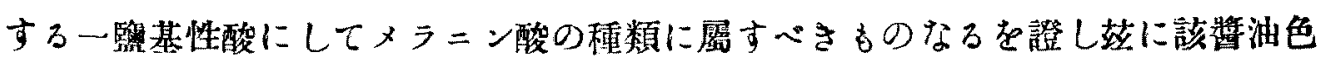
素に嶫しンヤメラニン酸（Soyamelanin Säure）の學名を與へたり

著者は最初該色素の水に不溶解性のバリウム監類こしてパリタ及炭酸バリウ ム等に依りて沈澱せらるる性質る利用して沈澱法に依りて直接醬油より定量せ んとしたるも夾雜物おり且つはバリ夕等に依りて完全に沈䬦せられざるを知り

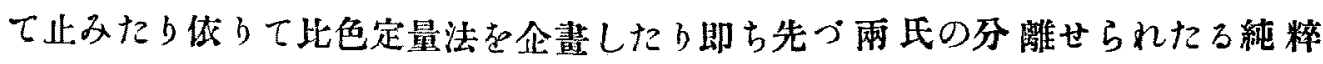


Soyamelanin Säure 溶液を基本さし約數百の水溶有機性色素を選抜して其色相全 く Soyamelanin Säure 溶液さ同一なるが如き標凖液の作謇を試みたり

元來 Soyamelanin Säure を溶存せる天然醬油の色相は赤色褐色或は黄色の單一 相には非らず前三者の色相を混有するに止らず更らに一種の暗黑色を帶ぶるを普 通さす之れ著者が該標準液の作製に甚だしく困難を感したる所以ならこす

著者が使用せる有機性色素は悉く單獨にてはSoyamelanin Säureの色相を呈せず 二，三種を混合併用するに至りて始めて該色相を現出するを認めてり然れごす此 際數程の色素の混合に依り沈澱物を生して色相不分明さなる。のおり或は互に 相反應し獨自の色調を減殺するが如きるのあり又は數日之を放置すれば酸化して 色度の增大或は褪色を爽するの等ありて一時的には色調全く Soyamelanin Säure 巳合致するす保存に㮱えざるもの多し著者は赤褐色部、黄褐色部、青篮色部より選 擇せる數種の色素を適當に配合し上記の父點を件はざる標準液を得たり即ち赤褐 色部より Echtbraun G. 黄褐色部より Säuregelb G. extra. を探り青笽色部上り 水溶性 Nigrosin t探用したり三種の色素混合液は純 Soyamelanin Säure 溶液こ 色相全く同一にして調製媵約一個年を經過したる今日に於ても何等篗色裉色する 事なく又沈澱物を生して其色調を笲すが如き事なし著者は該液の濃度を各種の濃 度に稀釋して夫々內徑一定せる硬質試驗管に密栓貯藏し各試驗每に醬油色素比色 定量標準液こして筫驗に供したり

該標淮液の原液は 100 c.c. 中 Säuregelb G. extra 0.2g. Echtbraun G. 0.1 g. 及水溶性 Nigrosin 0.02 g. 溶存し此溶液色度は純 Soyamelanin Säure の $2 \%$ 液に相當す依りて種々の謴度を異にせる標凖液を作れば原液のSoyamelanin Säure \%上り直ちにSoyamelanin\%に換算するを得へし依りて數多の標準液は Soyamelanin Säure\% こして表示したり濃度を異にせる各種の標凖液は之を同稆同長の

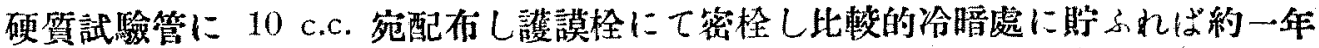
を綎過するも變色する事なく又色度の堽娍なく沈港物等を生ずる事なし

醬油及溜醬油のみならず其他の釀造物例へば清酒及麥酒等の特有色素成分は Soyamelanin Säure 性色素なるか否か今急に之を断ずる能はずを踓も Soyamelanin Säure 稀溥溶液に於ては满酒並に装酒を其色相全く同一にして外觀上何等の

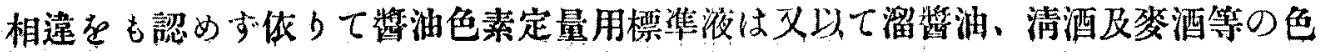


素定量に使用し得る事を確信す

實 驗

前記色素定量標準液に關して數百種の色素中より選擇せる水溶性有機色素の名 稱を舉ぐれば炏の如し

黃 褐 色部

1. Naphtholgelb $\mathrm{S}$

2. Immedial Orange

3. Flavazin

4. Chinolin gelb

5. Filmgelb G

6. Thiazol gelb

7. Rapid filter gelb

8. Säure gelb G. extra

9. Film gelb $\mathrm{T}$

赤褐 色 部

10. Echtbraun G

11. Korallin

12. Dicyanin

13. Alizerin rot

14. Phosphin $3 \mathrm{R}$

15. Benzopurpurin $6 \mathrm{R}$

16. Tropäolin $\mathrm{O}$

17. Orange $\mathrm{W}$

18. Orange $G$

19. Metanil gelb

20. Chrisanilin

21. Orange III

青 監 色 部

22. Bayrisch blau

23. Baumwoll blau

24. Janus blau $G$

25. Diamin blau $3 \mathrm{~B}$

26. Methylen blau $2 \mathrm{~B}$

27. Säureschwarz B

28. Dianilblau B

29. Säure Violet

30. Methylen blau B

31. Säure cyanin $G$

32. Toluidin blau

33. Nacht blau

34. 水溶性 Nigrosin

以上 34 棰の水溶性色素に就きて $0.1 \%$ 溶液を作り其 2 種或は 3 種を混合して 多數の組合せを作 b以て基淮純 Soyamelanin Säure 溶液飞比僌したり其色相基準

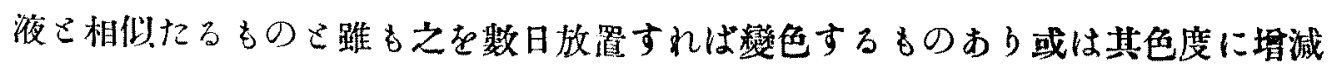
存桃して一定せざるすのあり或は沈澱物を生して混濁し以て色相不鮮明をなる。 の等ありて選擇甚だしく困難を感じたら最後に著者は次記の色素の適量を取って 
之を 100 c.c. 蒸溜水に溶解し其色相及色調全く純 Soyamelanin Säure 溶液に一致 する理想的の標準液を得たり
1. Säure gelb G. extra
$0.2 \mathrm{~g}$.
2. Echt braun G.
$0.1 \mathrm{~g}$.
3. 水溶性 Nigrosin $0.02 \mathrm{~g}$.

100 c.c. 蒸溜水に溶解す

該標準液の $0.5 \%$ 溶液の色度は $0.01 \%$ 純 Soyamelanin Säure $1 / 10$ 規定苛性曹達溶 液の色度を全然一致するを以て該 $0.5 \%$ 溶液は 100c.c. 中 0.01g. 純 Soyamelanin Säure を含有すを看做すを得へし從つて標準液 100c.c. 中に2g.の純 Soyamelanin Saure を含有すを假定せらろへし由りて該標潐液に就きて數多の㴗度の異な れる標隻液を作裂し其 Melanin Säure 含量を表示し置けば供試驗液を各標準液さ 比色し其一致したるを取り直ちに該試驗液の Melanin Säure 漂度を知る譯なり

清酒は憗酒等の如く淡色液は其一定量在取りて標準液を同徑同長の試驗管に入 れ直ちに試驗に供し得へしを踓も醬油の如き濃厚溶液は單に黑色を呈して色相不 鮮明なら故に之を適當の濃度例入ぱ $20 \%$ 溶液さなして試驗に供す

試驗に要する比色計は極微弱の色素の堽減等の測定に際してはドウボスク氏比 色計 (Duboscq's Colorimeter) 或はコバー氏比色計 (Kober's Colorimeter, Journ. of Biol. Chem., XXIX, P. 155) に依るへく普通はゼーレンゼン氏の使用したる

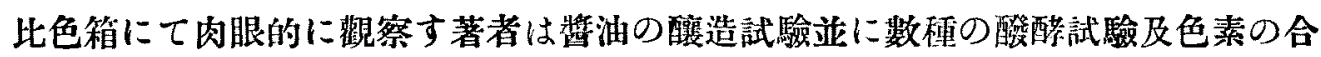

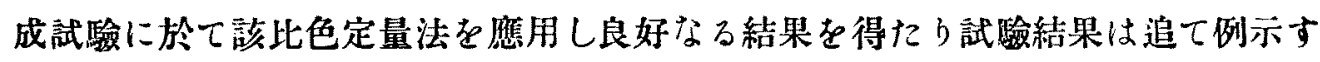
ベし

\section{Melanin 色素定量表}

(標淮波濃度は橴淮原㳸の百分等永示寸)

\begin{tabular}{|c|c|c|}
\hline 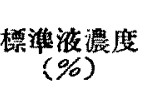 & 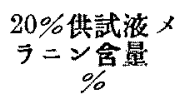 & 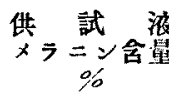 \\
\hline 0.100 & 0.002 & 0.010 \\
\hline 0.200 & 0.004 & 0.020 \\
\hline 0.300 & 0.006 & 0.030 \\
\hline 0.400 & 0.008 & 0.040 \\
\hline 0.500 & 0.010 & 0.050 \\
\hline 0.600 & 0.012 & 0.060 \\
\hline
\end{tabular}

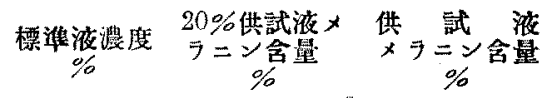

$0.700 \quad 0.014 \quad 0.070$

$\begin{array}{lll}0.800 & 0.016 & 0.080\end{array}$

$\begin{array}{lll}0.900 & 0.018 & 0.090\end{array}$

$\begin{array}{lll}1.000 & 0.020 & 0.100\end{array}$

$\begin{array}{lll}1.100 & 0.022 & 0.110\end{array}$

$\begin{array}{lll}1.200 & 0.024 & 0.120\end{array}$ 


\begin{tabular}{|c|c|c|c|c|c|}
\hline 1.300 & 0.026 & 0.130 & 5.100 & 0.102 & 0.510 \\
\hline 1.400 & 0.028 & 0.140 & 5.200 & 0.104 & 0.520 \\
\hline 1.500 & 0.030 & 0.150 & 5.300 & 0.106 & 0.530 \\
\hline 1.600 & 0.032 & 0.160 & 5.400 & 0.108 & 0.540 \\
\hline 1.700 & 0.034 & 0.170 & 5.500 & 0.110 & 0.550 \\
\hline 1.800 & 0.036 & 0.180 & 5.600 & 0.112 & 0.560 \\
\hline 1.900 & 0.038 & 0.190 & 5.700 & 0.114 & 0.570 \\
\hline 2.000 & 0.040 & 0.200 & 5.800 & 0.116 & 0.580 \\
\hline 2.100 & 0.042 & 0.210 & 5.900 & 0.118 & 0.590 \\
\hline 2.200 & 0.044 & 0.220 & 6.000 & 0.120 & 0.600 \\
\hline 2300 & 0.046 & 0.230 & 6.100 & $0 . \mathbf{I} 22$ & 0.610 \\
\hline 2.400 & 0.048 & 0.240 & 6.200 & 0.124 & 0.620 \\
\hline 2.500 & 0.050 & 0.250 & 6.300 & 0.126 & 0.630 \\
\hline 2.600 & 0.052 & 0.260 & 6.400 & 0.128 & 0.640 \\
\hline 2.700 & 0.054 & 0.270 & 6.500 & 0.130 & 0.650 \\
\hline 2.800 & 0.056 & 0.280 & 6.600 & 0.132 & 0.660 \\
\hline 2.900 & 0.058 & 0.290 & 6.700 & 0.134 & 0.670 \\
\hline 3.000 & 0.060 & 0.300 & 6.800 & 0.136 & 0.680 \\
\hline 3.100 & 0.062 & 0.310 & 6.900 & 0.138 & 0.990 \\
\hline 3.200 & 0.064 & 0.320 & 7.000 & 0.140 & 0.800 \\
\hline 3.300 & 0.066 & 0.330 & 7.100 & 0.142 & 0.710 \\
\hline 3.400 & 0.068 & 0.340 & 7.200 & 0.144 & 0.720 \\
\hline 3.500 & 0.070 & 0.350 & 7.300 & 0.146 & 0.730 \\
\hline 3.600 & 0.072 & 0.360 & 7.400 & 0.148 & 0.740 \\
\hline 3.700 & 0.074 & 0.370 & 7.500 & 0.150 & 0.750 \\
\hline $\mathbf{3 . 8 0 0}$ & 0.076 & 0.380 & 7.600 & 0.152 & 0.760 \\
\hline 3.900 & 0.078 & 0.390 & 7.700 & 0.154 & 0.770 \\
\hline 4.000 & 0.080 & 0.400 & 7.800 & 0.156 & 0.780 \\
\hline 4.100 & 0.082 & 0.410 & 7.900 & 0.158 & 0.790 \\
\hline 4.200 & 0.084 & 0.420 & 8.000 & 0.160 & 0.800 \\
\hline 4.300 & 0.086 & 0.430 & 8.100 & 0.162 & 0.810 \\
\hline 4.400 & 0.088 & 0.440 & 8.200 & 0.164 & 0.820 \\
\hline 4.500 & 0.090 & 0.450 & 8.300 & 0.166 & 0.830 \\
\hline 4.600 & 0.092 & 0.460 & 8.400 & 0.168 & 0.840 \\
\hline 4.700 & 0.094 & 0.470 & 8.500 & 0.170 & 0.850 \\
\hline 4.800 & 0.096 & 0.480 & 8.600 & 0.172 & 0.860 \\
\hline 4.900 & 0.098 & 0.490 & 8.700 & 0.174 & 0.870 \\
\hline 5.000 & 0.100 & 0.500 & 8.800 & 0.176 & 0.880 \\
\hline
\end{tabular}




\begin{tabular}{|c|c|c|c|c|c|}
\hline 8.900 & 0.178 & 0.890 & 12.400 & 0.248 & 1.240 \\
\hline 9.000 & 0.180 & 0.900 & 12.500 & 0.250 & 1.250 \\
\hline 9.100 & 0.182 & 0.910 & 12.600 & 0.252 & 1.260 \\
\hline 9.200 & 0.184 & 0.920 & 12.700 & 0.254 & 1.270 \\
\hline 9.300 & 0.186 & 0.930 & 12.800 & 0.256 & 1.280 \\
\hline 9.400 & 0.188 & 0.940 & 12,900 & 0.258 & 1.290 \\
\hline 9.500 & $0 . \mathrm{I} 90$ & 0.950 & 13.000 & 0.260 & 1.300 \\
\hline 9.600 & 0.192 & 0.960 & 13.100 & 0.262 & 1.310 \\
\hline 9.700 & 0.194 & 0.970 & 13.200 & 0.264 & 1.320 \\
\hline 9.800 & 0.196 & 0.980 & 13.300 & 0.266 & 1.330 \\
\hline 9.900 & 0.198 & 0.990 & 13.400 & 0.268 & 1.340 \\
\hline 10.000 & 0.200 & 1.000 & 13.500 & 0.270 & 1.350 \\
\hline 10.100 & 0.202 & 1.010 & 13.600 & 0.272 & 1.360 \\
\hline 10.200 & 0.204 & 1.020 & 13.700 & 0.274 & 1.370 \\
\hline 10.300 & 0.206 & 1.030 & 13.800 & 0.276 & 1.380 \\
\hline 10.400 & 0.208 & 1.040 & 13.900 & 0.278 & 1.390 \\
\hline 10.500 & 0.210 & 1.050 & 14.000 & 0.280 & 1.400 \\
\hline 10.600 & 0.212 & 1.060 & 14.100 & 0.282 & 1.410 \\
\hline 10.700 & 0.214 & 1.070 & 14.200 & 0.284 & 1.420 \\
\hline 10.800 & 0.216 & 1.080 & 14.300 & 0.286 & 1.430 \\
\hline 10.900 & 0.218 & 1.090 & 14.400 & 0.288 & 1.440 \\
\hline 11.000 & 0.220 & 1.100 & 14.500 & 0.290 & 1.450 \\
\hline 11.100 & 0.222 & 1.110 & 14.600 & 0.292 & 1.460 \\
\hline 11.200 & 0.224 & 1.120 & 14.700 & 0.294 & 1.470 \\
\hline 11.300 & 0.226 & 1.130 & 14.800 & 0.296 & 1.480 \\
\hline 11.400 & 0.228 & 1.140 & 14.900 & 0.298 & 1.490 \\
\hline 11.500 & 0.230 & 1.150 & 15.000 & 0.300 & 1.500 \\
\hline 11.600 & 0.232 & 1.160 & 15.100 & 0.302 & 1.510 \\
\hline 11.700 & 0.234 & 1.170 & 15.200 & 0.304 & 1.520 \\
\hline 11.800 & 0.236 & 1.180 & 15.300 & 0.306 & 1.530 \\
\hline 11.900 & 0.238 & 1.190 & 15.400 & 0.308 & 1.540 \\
\hline 12.000 & 0.240 & 1.200 & 15.500 & 0.310 & 1.550 \\
\hline 12.100 & 0.242 & 1.210 & 15.600 & 0.312 & 1.560 \\
\hline 12.200 & 0.244 & 1.220 & 15.700 & 0.314 & 1.570 \\
\hline 12.300 & 0.246 & 1.230 & 15.800 & 0.316 & 1.580 \\
\hline
\end{tabular}




\begin{tabular}{|c|c|c|c|c|c|}
\hline 15.900 & 0.318 & 1.590 & 19.400 & 0.388 & 1.940 \\
\hline 16.000 & 0.320 & 1.600 & 13.500 & 0.390 & 1.950 \\
\hline 16.100 & 0.322 & 1.610 & 19.600 & 0.392 & 1.960 \\
\hline 16.200 & 0.324 & 1.620 & 19.700 & 0.394 & 1.970 \\
\hline 16.300 & 0.326 & 1.630 & 19.800 & 0.396 & 1.980 \\
\hline 16.400 & 0.328 & 1.640 & 19.900 & 0.398 & 1.990 \\
\hline 16.500 & 0.330 & 1.650 & 20.000 & 0.400 & 2.000 \\
\hline 16.600 & 0.332 & 1.660 & 20.100 & 0.402 & 2.010 \\
\hline 16.700 & 0.334 & 1.670 & 20.200 & 0.404 & 2.020 \\
\hline 16.800 & 0.336 & 1.680 & 20.300 & 0.406 & 2.030 \\
\hline 16.900 & 0.338 & 1.690 & 20.400 & 0.408 & 2.040 \\
\hline 17.000 & 0.340 & 1.700 & 20.500 & 0.410 & 2.050 \\
\hline 17.100 & 0.342 & 1.710 & 20.600 & 0.412 & 2.060 \\
\hline 17.200 & 0.344 & 1.720 & 20.700 & 0.414 & 2.070 \\
\hline 17.300 & 0.346 & 1.730 & 20.800 & 0.416 & 2.080 \\
\hline 17.400 & 0.348 & 1.740 & 20.900 & 0.418 & 2,090 \\
\hline 17.500 & 0.350 & 1.750 & 21.000 & 0.420 & 2.100 \\
\hline 17.600 & 0.352 & 1.760 & 21.100 & 0.422 & 2.110 \\
\hline 17.700 & 0.354 & 1.770 & 21.200 & 0.424 & 2.120 \\
\hline 17.800 & 0.356 & 1.780 & 21.300 & 0.426 & 2.130 \\
\hline 17.900 & 0.358 & 1.790 & 21.400 & 0.428 & 2.140 \\
\hline 18.000 & 0.360 & 1.800 & 21.500 & 0.430 & 2.150 \\
\hline 18.100 & 0.362 & 1.810 & 21.600 & 0.432 & 2.160 \\
\hline 18.200 & 0.364 & 1.820 & 21.700 & 0.434 & 2.170 \\
\hline 18.300 & 0.366 & 1.830 & 21.800 & 0.436 & 2.180 \\
\hline 18.400 & 0.368 & $1 \cdot 840$ & 21.900 & 0.438 & 2.190 \\
\hline 18.500 & 0.370 & 1.850 & 22.000 & 0.440 & 2.200 \\
\hline 18.600 & 0.372 & 1.860 & 22.100 & 0.442 & 2.210 \\
\hline 18.700 & 0.374 & 1.870 & 22.200 & 0.444 & 2.220 \\
\hline 18.800 & 0.376 & 1.880 & 22.300 & 0.446 & 2.230 \\
\hline 18.900 & 0.378 & 1.890 & 22.400 & 0.448 & 2.240 \\
\hline 19.000 & 0.380 & 1.900 & 22.500 & 0.450 & 2.250 \\
\hline 19.100 & 0.382 & 1.100 & 22.600 & 0.452 & 2.260 \\
\hline 19.200 & 0.384 & 1.920 & 22.700 & 0.454 & 2.270 \\
\hline 19.300 & 0.386 & 1.930 & 22.800 & 0.456 & 2.280 \\
\hline
\end{tabular}




\begin{tabular}{|c|c|c|c|c|c|}
\hline 22.900 & 0.458 & 3.290 & 26.400 & 0.528 & 2.640 \\
\hline 23.000 & 0.460 & 2.300 & 26.500 & 0.530 & 2.650 \\
\hline 23.100 & 0.462 & 2.310 & 26.600 & 0.532 & 2.660 \\
\hline 23.200 & 0.464 & 2,330 & 26.700 & 0.534 & 2.670 \\
\hline 23.300 & 0.466 & 2.330 & 26.800 & 0.536 & 2.680 \\
\hline 23.400 & 0.468 & 2.340 & 26.900 & 0.588 & 2.690 \\
\hline 23.500 & 0.470 & 2.350 & 27.000 & 0.540 & 2.700 \\
\hline 23.600 & 0.472 & 2.360 & 27.100 & 0.542 & 2.710 \\
\hline 23.700 & 0.474 & 2.370 & 27.200 & 0.544 & 2.720 \\
\hline 23.800 & 0.476 & 2.380 & 27.300 & 0.546 & 3.730 \\
\hline 23.900 & 0.478 & 2.390 & 27.400 & 0.548 & 2.740 \\
\hline 24.000 & 0.480 & 2.400 & 27.500 & 0.550 & 2.750 \\
\hline 24.100 & 0.482 & 2.410 & 27.600 & 0.552 & 2.760 \\
\hline 24.200 & 0.484 & 2.420 & 27.700 & 0.554 & 2.770 \\
\hline 24.300 & 0.486 & 2.430 & 27.800 & 0.556 & 2.780 \\
\hline 24.400 & 0.488 & 2.440 & 27.900 & 0.558 & 2.790 \\
\hline 24.500 & 0.490 & 2.450 & 28.000 & 0.560 & 2.800 \\
\hline 24.600 & 0.492 & 2.460 & 28.100 & 0.562 & 2.810 \\
\hline 24.700 & 0.494 & 2.470 & 28.200 & 0.564 & 2.820 \\
\hline 24.800 & 0.496 & 2.480 & 28.300 & 0.566 & 2.830 \\
\hline 24.900 & 0.498 & 0.490 & 28.400 & 0.568 & 2.840 \\
\hline 25.000 & 0.500 & 2.500 & 28.500 & 0.570 & 2.850 \\
\hline 25.100 & 0.502 & 2.510 & 28.600 & 0.572 & 2.860 \\
\hline 25.200 & 0.504 & 2.520 & 28.700 & 0.574 & 2.870 \\
\hline 25.300 & 0.506 & 2,530 & 28.800 & 0.576 & 2.880 \\
\hline 25.400 & 0.508 & 2.540 & 28.900 & 0578 & 2.890 \\
\hline 25.500 & 0.510 & 2.550 & 29.000 & 0.580 & 2.900 \\
\hline 25.600 & 0.512 & 2.560 & 29.100 & 0.582 & 2.910 \\
\hline 25.700 & 0.514 & 2.570 & 29.200 & 0.584 & 2.920 \\
\hline 25.800 & 0.516 & 2.580 & 29.300 & 0.586 & 2.930 \\
\hline 25.900 & 0.518 & 2.590 & 29.400 & 0.588 & 2.940 \\
\hline 26.000 & 0.520 & 2.600 & 29.500 & 0.590 & 2.950 \\
\hline 26.100 & 0.522 & 2.610 & 29.600 & 0.592 & 2.960 \\
\hline 26.200 & 0.524 & 2.620 & 29.700 & 0.594 & 2.970 \\
\hline 26.300 & 0.526 & 2.630 & 29.800 & 0.596 & 2.980 \\
\hline
\end{tabular}


1. 鼠油より芀離したる純 Soyamelanin Säure 色素の苛性曹達溶液を基本こし

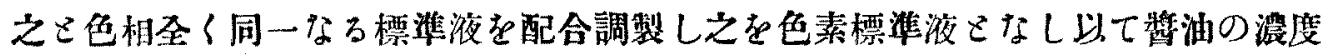
在比色的に测定する力法を菜出したb

2. 蒸溜水 100c.c. 中 Säure gelb G. extra 0.2g., Echt braun G. 0.1g. 及び水溶 性 Nigrosin 0.02g. 溶存するを標準原液さなし（該液は Soyamelanin Säure の $2 \%$ 液に相當す）之より湄度を異にする數百種の色素標潗液を作製し Melanin 定 量表によりて直ちに該液の Melanin 百分率る知り得るが如くす

3. 該標準液は時間の經過によりて秋色螁色沈澱等を起さす常に一定の色度を 保持す

4. 該定量法は醬油、溜醬油のみならず清酒、麥酒等の色素定量に應用するる 得へし

5. 該定量法は釀造試驗並に學術研究に於ける總ての Melanin 性色素研究に推 獎するを得へし

終りに知み黑野先生の御留篤なる御指導に深謝す

(䀲造 試 驗 所) 